\title{
INFLUENCE OF THE CONDENSER AND EVAPORATOR AIR FLOWS ON THE CONDENSATION AND EVAPORATION PRESSURES OF AIR SPLIT-CONDITIONERS HEAT PUMPS
}

\author{
Department Heat and Gas Supply and Ventilation, \\ Lviv Polytechnic National University \\ wlabay@i.ua
}

(C) Labay V., Yaroslav V., Dovbush O., Tsizda A., 2020

In the face of growing shortages and rising prices for fuel and energy resources, the problem of energy conservation and the use of alternative energy sources to solve the problem of reducing energy consumption for the Ukrainian economy become very important. Today, the use of air splitconditioner heat pumps in buildings' heating systems is becoming more common. Therefore, the improvement of the design and operation of power equipment to which air split-conditioner heat pumps ("air-air") are related is related to a detailed study of their operation and an objective assessment of their degree of energy perfection, which can only be determined on the basis of analysis their exergy efficiency. This made it possible to substantiate the relevance of such a research task due to the insufficient information on the operating modes related to the influence of air flows on the condenser and evaporator on the corresponding condensation and evaporation pressures and the exergetic efficiency of the use of air split-conditioners. For this article it was used the author's innovation mathematical model to analysis of the operation of one-step freon heat pumps, which are used in air split-conditioners, according to the exergetic method. The dependence of condensation and evaporation pressures and exergetic output-input ratio (OIR) on the example of „Mitsubishi Electric” firm air split-conditioner heat pump with the nominal heating capacity of $3067 \mathrm{~W}$ under the standard external temperature conditions on the refrigerant $\mathbf{R} 32$ was determined from the condenser and evaporator air flows.

Key words: heat pump, air split-conditioner, condensation and evaporation pressures, condenser and evaporator air flows, exergetic efficiency

\section{Introduction}

In the face of growing shortages and rising prices for fuel and energy resources, the problem of energy saving and the use of alternative energy sources to solve the problem of reducing energy consumption for the Ukrainian economy becomes very actually (Energy Strategy of Ukraine, 2013).

A significant reduction in the use of traditional organic energy sources for building heating is possible thanks to, for example, heat pumps (HP) ("air-to-air") of air split-conditioners, that use renewable energy. Today, the use of air split-conditioners heat pumps in building's heat supply systems is becoming more common (Bezrodniy, 2013; Zalewski, 2001; Shargut, 1968; Sokolov, 1981; Morozyuk, 2006). This is due to the fact that, by consuming $1 \mathrm{~kW}$ of electricity, HP air split-conditioners can carry up to $5 \mathrm{~kW}$ of energy for heating the room air. The use of HP provides not only energy-saving but also environmental impact.

According to the World Energy Committee, by 2020, $75 \%$ of heat supply (municipal and industrial) in developed countries will be supplied by heat pumps. In the USA, more than $30 \%$ of residential homes are equipped with HP.

Currently for Ukraine the problem of saving energy resources is particularly relevant in conditions of market economy, limited resources of primary energy commodities - oil and gas. 
In recent decades both abroad and in Ukraine with the aim of saving energy resources, fundamental research in a number of industries and technologies from the standpoint of exergetic methodology have been conducted (Shargut, 1968; Sokolov, 1981; Silvio, 2013; Bejan, 1988; Bejan, 1996; Morosuk, 2006; Morozyuk, 2006; Tsatsaronis, 2002; Labay, 2018; Labay, 2008).

Exergy not only quantifies energy of any kind, but also allows estimate its quality. It defines the convergence, suitability of energy for its technical use in any conditions.

Since exergy is the only measure of the work ability, that is, suitability of energy resources for use, it enables to objectively evaluate the energy resources of any kind. Consequently, exergy is some universal measure of the suitability of energy resources. And the exergetic balance, on the basis of which the volume of energy resources is set, indicates the possibility of increasing the OIR of the process.

In some leading European countries and in USA exergy analysis has been introduced as a mandatory component in development of projects and plans of modernization of manufacturing.

\section{Target of this article}

The purpose of this work is to determine the condensation and evaporation pressures of the air split-conditioner heat pump, depending on its air capacity on the condenser and evaporator, and to determine air flow optimal values for the air split-conditioner heat pump on the condenser and evaporator. For this needed to install:

- the condensation and evaporation pressures and the exergetic output-input ratio (OIR) of "Mitsubishi Electric" air split-conditioner heat pump of $3067 \mathrm{~W}$ heat capacity at standard temperature test conditions depending on the condenser and evaporator air flow;

- analytical dependences between the condensation and evaporation pressures of "Mitsubishi Electric" air split-conditioner heat pump and respectively the condenser and evaporator air flow;

- optimum air flow values on the condenser and evaporator of the air conditioner heat pump.

This was the task of research.

\section{Techniques used}

Air split-conditioners have achieved some technical improvements that are used as heat pumps to create a suitable microclimate in small rooms during the cold season. To further increase the efficiency of these air split-conditioners heat pumps, a detailed analysis of their operation is required using a modern exergetic thermodynamic analysis method (Sokolov, 1981; Shargut, 1968).

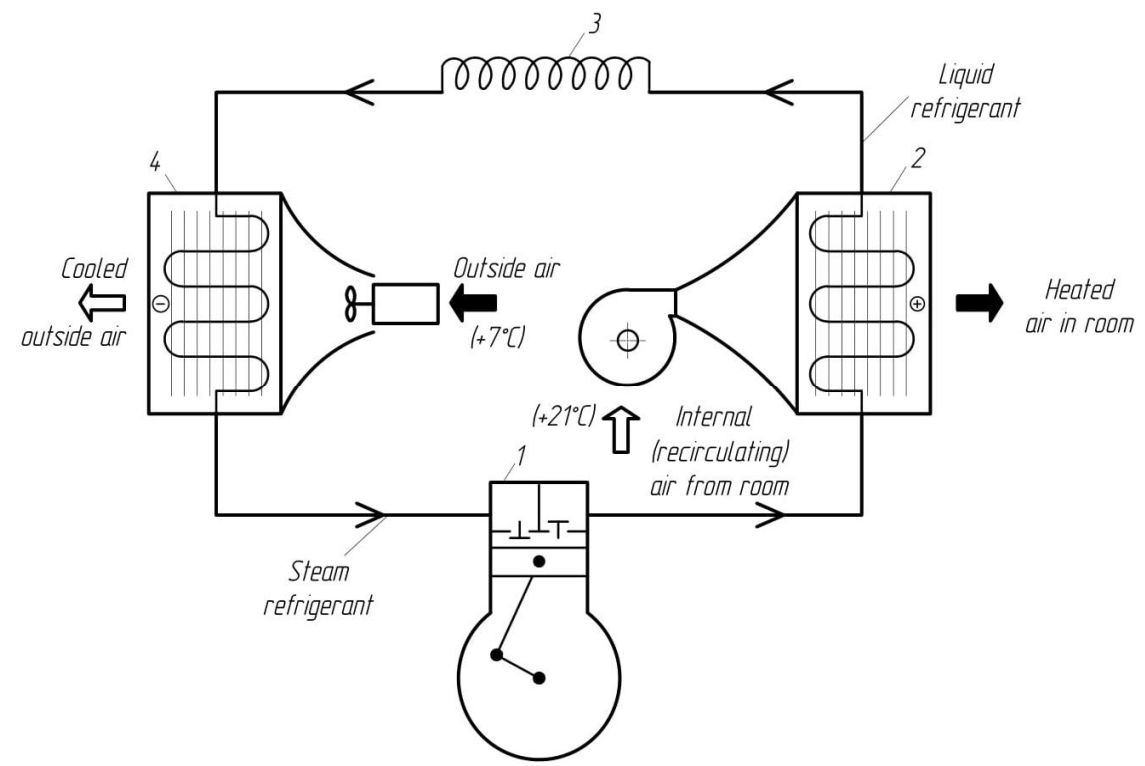

Fig. 1. Scheme of air split-conditioner heat pump: 1 is compressor; 2 is condenser; 3 is capillary tube; 4 is evaporator 
For this purpose, the authors developed and used in this article the exergetic method of analyzing the operation of one-step freon heat pumps (without effective cooling of the compressor) of air splitconditioners. In this method, the scheme of the heat pump shown in Fig. 1 and the corresponding construction of the processes of its operation on the $p, i$-diagram - in Fig. 2 and work agent refrigerant-32 (R32) (Jakobsen, 2001), are used.

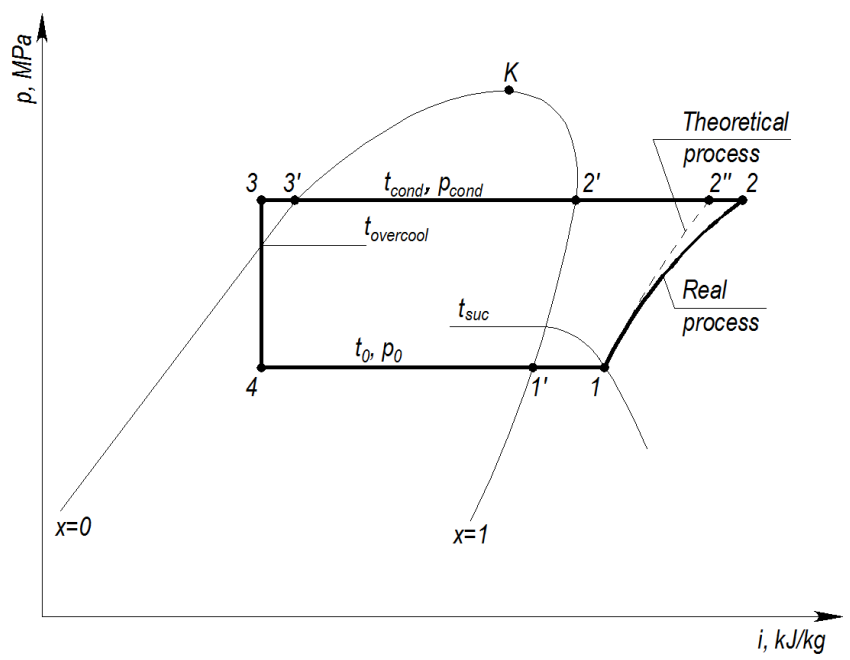

Fig. 2. Construction of the processes of work on p,i-diagram for heat pump

of air split-conditioner: 1, 2, 3, 4 are characteristic points of the thermodynamic cycle

\section{Research results}

The results of researches are summarized in Table 1 and in Fig. 2 and 3 dependence of the condensation and evaporation pressures of the "Mitsubishi Electric" air split-conditioner heat pump of $3067 \mathrm{~W}$ heat capacity at standard temperature conditions, namely, indoor air temperature $t_{\text {in }}=t_{H_{1}}=+21^{\circ} \mathrm{C}$ and outdoor air $-t_{\text {out }}=t_{C_{1}}=+7{ }^{\circ} \mathrm{C}$, respectively, depending on the air flow rate of the condenser and the evaporator are shown.

Table 1

Results of exergetic output-input ratio (OIR) and the condensation and evaporation pressures air split-conditioner "Mitsubishi Electric" with heat capacity of $3067 \mathrm{~W}$ under standard conditions depending on the air flow rate of the condenser and the evaporator

\begin{tabular}{|c|c|c|c|c|c|c|}
\hline$L_{\text {cond }}, \mathrm{m}^{3} / \mathrm{h}$ & $L_{e v}, \mathrm{~m}^{3} / \mathrm{h}$ & $t_{\text {cond }},{ }^{\circ} \mathrm{C}$ & $t_{0}=t_{e v},{ }^{\circ} \mathrm{C}$ & $p_{\text {cond }}, \mathrm{MPa}$ & $p_{0}=p_{e v}, \mathrm{MPa}$ & $\eta_{\mathrm{e}}$ \\
\hline 1 & 2 & 3 & 4 & 5 & 6 & 7 \\
\hline 300 & 1507 & 55.3 & 0.7 & 3.48 & 0.83 & 0.386 \\
\hline 400 & $-"-$ & 47.7 & $-"-$ & 3.00 & $-"-$ & 0.385 \\
\hline 500 & $-"-$ & 43.2 & $-"-$ & 2.71 & $-"-$ & 0.382 \\
\hline 600 & $-"-$ & 40.2 & $-"-$ & 2.52 & $-"-$ & 0.380 \\
\hline 700 & $-"-$ & 38.1 & $-"-$ & 2.39 & $-"-$ & 0.378 \\
\hline 800 & $-"-$ & 36.5 & $-"-$ & 2.30 & $-"-$ & 0.377 \\
\hline 900 & $-"-$ & 35.2 & $-"-$ & 2.22 & $-"-$ & 0.376 \\
\hline 1000 & $-"-$ & 34.2 & $-"-$ & 2.17 & $-"-$ & 0.375 \\
\hline 614 & 500 & 39.9 & -6.4 & 2.50 & 0.63 & 0.327 \\
\hline$-"-$ & 1000 & 15.0 & -1.1 & $-"-$ & 0.78 & 0.365 \\
\hline$-"-$ & 2000 & $-"-$ & 1.6 & $-"-$ & 0.86 & 0.388 \\
\hline$-"-$ & 3000 & $-"-$ & 2.4 & $-"-$ & 0.88 & 0.397 \\
\hline
\end{tabular}


Continuation of table 1

\begin{tabular}{|c|c|c|c|c|c|c|}
\hline 1 & 2 & 3 & 4 & 5 & 6 & 7 \\
\hline$-"-$ & 4000 & $-"-$ & 2.9 & $-"-$ & 0.90 & 0.401 \\
\hline$-"-$ & 5000 & $-"-$ & 3.1 & $-"-$ & 0.90 & 0.404 \\
\hline$-"-$ & 6000 & $-"-$ & 3.3 & $-"-$ & 0.91 & 0.406 \\
\hline$-"-$ & 7000 & $-"-$ & 3.4 & $-"-$ & 0.91 & 0.407 \\
\hline 614 & 1507 & 39.9 & 0.7 & 2.50 & 0.83 & 0.380 \\
\hline $\mathbf{4 0 0}$ & $\mathbf{3 5 0 0}$ & $\mathbf{4 7 . 7}$ & $\mathbf{2 . 7}$ & $\mathbf{3 . 0 0}$ & $\mathbf{0 . 8 9}$ & $\mathbf{0 . 4 0 1}$ \\
\hline
\end{tabular}

Table 1 shows italicized standard mode and bolded - offered.

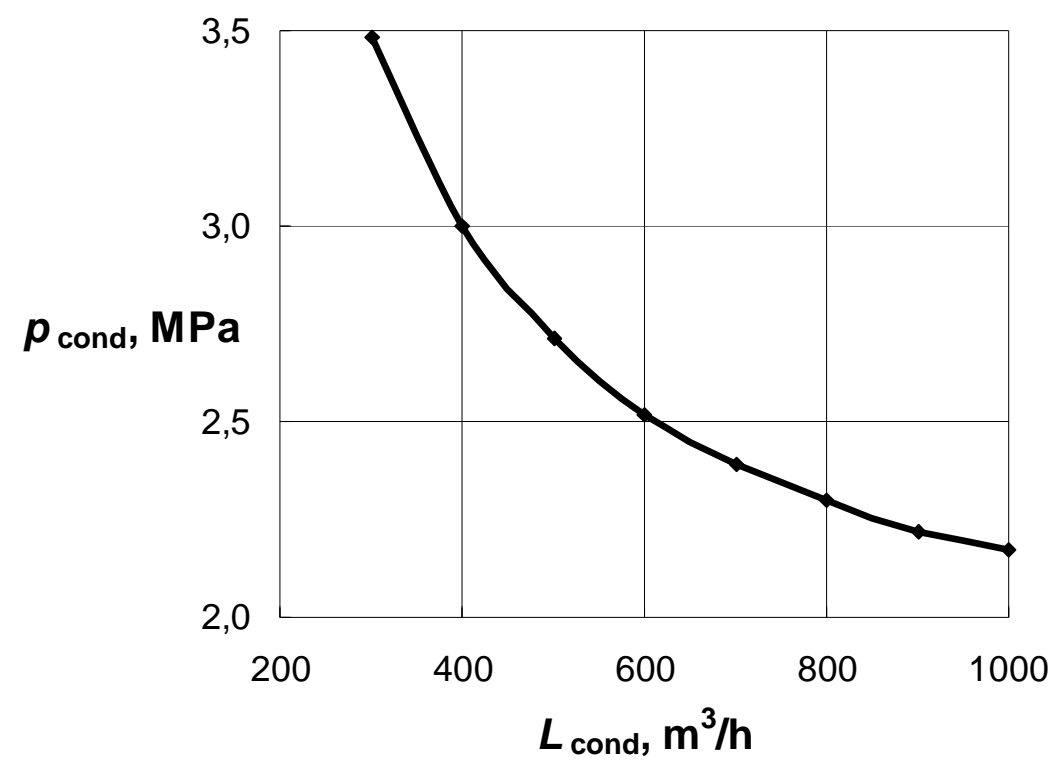

Fig. 3. Dependence of the condensation pressure of "Mitsubishi Electric" air split-conditioner heat pump with heat capacity of $3067 \mathrm{~W}$ under standard conditions from the condenser air flow

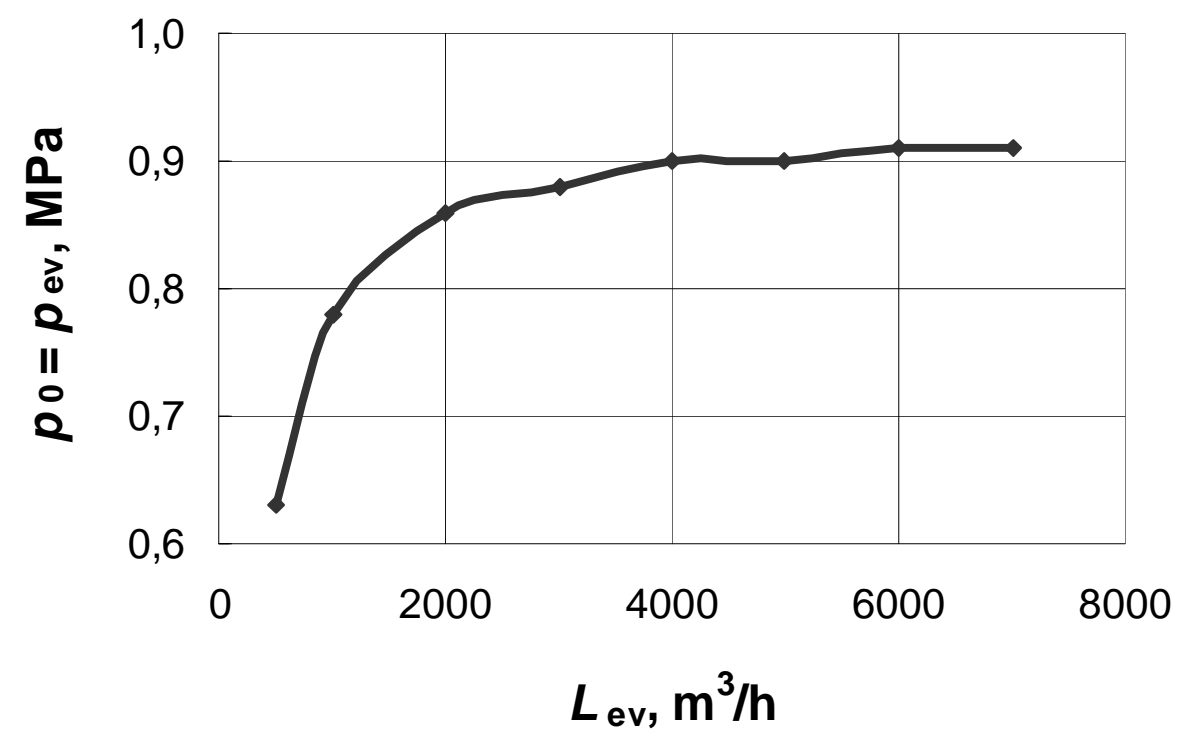

Fig. 4. Dependence of the evaporation pressure of "Mitsubishi Electric" air split-conditioner heat pump with heat capacity of $3067 \mathrm{~W}$ under standard conditions from the evaporator air flow 
Here $L_{c o n d}, L_{e v}$ - respectively, the air flow rate in the condenser and the evaporator of the air conditioner, $\mathrm{m}^{3} / \mathrm{h} ; t_{H_{1}}$ - air temperature at the inlet of the air conditioner condenser, ${ }^{\circ} \mathrm{C} ; t_{C_{1}}-$ air temperature at the inlet of the air conditioner evaporator, ${ }^{\circ} \mathrm{C} ; t_{\text {cond }}-$ the condensation temperature of the refrigerant in the air conditioner, ${ }^{\circ} \mathrm{C} ; t_{e v}-$ evaporation temperature of the refrigerant in the air conditioner, ${ }^{\circ} \mathrm{C} ; p_{\text {cond }}-$ condensation pressure of the refrigerant in the air conditioner, MPa; $p_{e v}-$ evaporation pressure of the refrigerant in the air conditioner, MPa; $\eta_{e}$ - exergetic output-input ratio (OIR) of the air split-conditioner heat pump.

From the Table 1 that due to the proposed optimal air flow rate on the condenser and the evaporator of the air split-conditioner heat pump the exergetic OIR increases by $(0.401-0.380) \cdot 100 / 0.380=5.5 \%$ are showed, which is significant.

The results of researches of the condensation and evaporation pressures of the "Mitsubishi Electric" air split-conditioner heat pump of $3067 \mathrm{~W}$ under standard conditions, depending on the air flow rate, respectively, on the condenser and the evaporator of conditioner, are approximated by the following formulas:

$$
\begin{aligned}
\text { - 3a } L_{\text {cond }}=300 \ldots 1000 \mathrm{~m}^{3} / \mathrm{h} \text { and } L_{e v} & =1507 \mathrm{~m}^{3} / \mathrm{h}: \\
p_{\text {cond }} & =1.61+561 \cdot L_{\text {cond }}^{-1}, \mathrm{MPa} \\
\text { - 3a } L_{e v}=500 \ldots 7000 \mathrm{~m}^{3} / \mathrm{h} \text { and } L_{c o n d} & =614 \mathrm{~m}^{3} / \mathrm{h}: \\
p_{0}=p_{e v} & =0.93-151 \cdot L_{e v}^{-1}, \mathrm{MPa} .
\end{aligned}
$$

The maximum error according to the formula (1) is $1,0 \%$, and the formula (2) is $0.9 \%$.

\section{Conclusions}

Analyzing the data obtained in the table 1 and in Fig. 3 and 4, one can come to the following conclusions.

An increase in the air flow rate on the condenser of the air conditioner heat pump $L_{c o n d}$ from 300 to $1000 \mathrm{~m}^{3} / \mathrm{h}$ has almost no effect on the change in the value of the exergetic OIR $\eta_{e}(0.386-$ $-0.375) \cdot 100 / 0.386=2.85 \%$, but leads to a significant decrease in the condensation pressure $p_{\text {cond }}(3.48-2.17) \cdot 100 / 3.48=37.6 \%$, which is positive from a structural point of view. Therefore, it is desirable to use as little as possible air flow rate $L_{\text {cond }}$ on the air conditioner condenser (for example $L_{\text {cond }}=400 \mathrm{~m}^{3} / \mathrm{h}$ ) and appropriate condensation pressure $\left(p_{\text {cond }}=3.0 \mathrm{MPa}\right)$. It should be noted that the increase in condensation pressure $p_{\text {cond }}$ compared to the standard process is negligible $(3.0-2.5) \cdot 100 / 2.5=20 \%$.

However, with the increase of air flow rate on the evaporator of the air conditioner heat pump $L_{e v}$ from 500 to $4000 \mathrm{~m}^{3} / \mathrm{h}$ leads to a significant increase in the value of exergetic OIR $\eta_{e}(0.401-$ $-0.327) \cdot 100 / 0.327=23 \%$ due to the increase of the evaporation pressure $p_{e v}(0.90-0.63) \cdot 100 / 0.63=$ $=43 \%$, which is negative from a structural point of view. With the further increase of air flow rate $L_{e v}$ from 4000 to $7000 \mathrm{~m}^{3} / \mathrm{h}$, the value of the exergetic OIR $\eta_{e}$ increases slightly $(0.407-0.401) \cdot 100 / 0.401=$ $=1.5 \%$ with a slight increase in the evaporation pressure $p_{e v}(0.91-0.90) \cdot 100 / 0.90=1.1 \%$. Therefore, it is desirable to use as much air flow rate $L_{e v}$ as possible on the air conditioner evaporator maximum (for example $3500 \mathrm{~m}^{3} / \mathrm{h}$ ) and appropriate evaporation pressure ( $\left.p_{e v}=0.89 \mathrm{MPa}\right)$. It is worth noting that the 
increase in the evaporation pressure $p_{e v}$ compared to the standard process is quite insignificant $(0.89-$ $-0.83) \cdot 100 / 0.83=7.2 \%$.

According to the results of the analysis of the obtained data, the optimal air flow rates on the condenser and evaporator of the "Mitsubishi Electric" air split-conditioner heat pump with a heat capacity of $3067 \mathrm{~W}$ are offered under standard conditions and condensation and evaporation pressures, respectively: on the condenser $-L_{c o n d}=400 \mathrm{~m}^{3} / \mathrm{h}$ and $p_{\text {cond }}=3.0 \mathrm{MPa}$, and at the evaporator $-L_{e v}=$ $=3500 \mathrm{~m}^{3} / \mathrm{h}$ and $p_{e v}=0.89 \mathrm{MPa}$.

So, developed by the authors and used for this article the innovative mathematical model of exergetic analysis of the operation of one-step freon air split-conditioners heat pumps allows to determine the exergetic OIR of the air split-conditioner heat pump, as well as to optimize its operation.

\section{References}

Energy Strategy of Ukraine until 2030 (2013) [Electronic resource]. - Access mode: - http://www.ukrenergo. energy.gov.ua (in Ukrainian).

Bezrodniy M. N., Dranik T. V. (2013) Thermodynamic efficiency of heat pump application for providing comfortable conditions in indoor pools. Eastern European Journal of Enterprise Technologies 3 (8), 25-30 (in Ukrainian).

Zalewski P. K. (2001) Pompy ciepła. Podstawy teoretyczne i przykłady zastosowania. I.P.P.U. MASTA Sp. z o.o., Kraków (in Polish).

Shargut E., Petela R. (1968) Exergy. Moscow: Energy (in Russian).

Sokolov E. Ya., Brodiansky V. M. (1981) Energy bases of heat transformation and cooling processes. Moscow: Energoizdat (in Russian).

Silvio de Oliveira Junior. (2013) Exergy. Production, Cost and Renewability. Springer (in English).

Bejan A. (1988) Advanced Engineering Thermodynamics. New York: J. Wiley (in English).

Bejan A., Tsatsaronis G., Moran M. (1996) Thermal Design and Optimization. New York: J. Wiley (in English).

Morosuk T., Nikulshin R., Morosuk L. (2006) Entropy-Cycle Method for Analysis of Refrigeration Machine and Heat Pump Cycles. THERMAL SCIENCE 10 (1), 111-124 (in English).

Morozyuk T. V. (2006) The theory of refrigeration machines and heat pumps. Odessa: Studio "Negotsiant" (in Russian).

Tsatsaronis J. (2002) The interaction of thermodynamics and economics to minimize the cost of an energy conversion system. Odessa: Studio "Negotsiant" (in Russian).

Labay V., Dovbush O., Yaroslav V. and Klymenko H. (2018) Mathematical Modeling of a Split-conditioner Operation for Evaluation of Exergy Efficiency of the R600A Refrigerant Application. Scientific Journal "Mathematical Modeling and Computing" (Математичне моделювання та інформаційні технології) 5 (2), 169177 (in English).

Labay V. Yo., Khanyk Ya. M. (2008) Energy Saving Ratio Between the Air Flows at the Evaporator and Condenser Air Split-conditioners. Scientific and Technical Journal "Refrigeration Engineering and Technology" 6 (116), 28-31 (in Ukrainian).

Jakobsen A., Rassmussen B.-D., Skovrup M.-J., Andersen S.-E. (2001) CoolPack - a collection of simulation tools for refrigeration - Tutorial - Version 1.46. - Department of Energy Engineering Technical University of Denmark (in English).

Mitsubishi Electric Catalogo Split (2019) (in English). 
В. Й. Лабай, В. Ю. Ярослав, О. М. Довбуш, А. Цізда Національний університет “Львівська політехніка", кафедра теплогазопостачання і вентиляції

\section{ВПЛИВ ПОВІТРЯНИХ ПОТОКІВ НА КОНДЕНСАТОРІ І ВИПАРНИКУ НА ТИСКИ КОНДЕНСАЦЇ̈ І ВИПАРОВУВАННЯ ТЕПЛОВИХ ПОМП SРLIT-КОНДИЦІОНЕРІВ}

С Лабай В. Й., Ярослав В. Ю., Довбуш О. М., Цізда А., 2020

В умовах зростаючого дефіциту та росту цін на паливно-енергетичні ресурси проблема енергозбереження та використання альтернативних джерел енергії для вирішення проблеми зменшення енергоспоживання для економіки України стає дуже важливою. Сьогодні стає все розповсюдженішим використання теплових помп split-кондиціонерів у системах теплопостачання будівель. Тому вдосконалення конструкції і роботи енергетичного обладнання, до якого належать теплові помпи split-кондиціонерів (“повітря-повітря”), пов’язане з детальним вивченням їх роботи та об'єктивною оцінкою ступеня їх енергетичної досконалості, що може бути визначена лише на основі аналізу їх ексергетичної ефективності. Це дозволило обгрунтувати актуальність такого дослідницького завдання, що пов'язано 3 недостатньою інформацією щодо режимів роботи, пов'язаних із впливом потоків повітря на конденсаторі і випарнику на відповідні тиски конденсації і випаровування, та ексергетичної ефективності використання теплових помп split-кондиціонерів. Для цієї статті використано авторську інноваційну математичну модель для аналізу роботи одноступеневих фреонових теплових помп, які використовуються у split-кондиціонерах, за ексергетичним методом. Встановлено залежність тисків конденсації і випаровування та ексергетичного ККд на прикладі теплової помпи split-кондиціонера фірми „Mitsubishi Electric” з номінальною теплопродуктивністю 3067 Вт за стандартних зовнішніх температурних умов на холодильному агенті R32 від потоків повітря на конденсаторі і випарнику.

Ключові слова: теплова помпа, split-кондиціонер, тиски конденсації i випаровування, потоки повітря на конденсаторі і випарнику, ексергетична ефективність 